\title{
Effect of complete feed blocks or grazing and supplementation of lambs on performance, nutrient utilisation, rumen fermentation and rumen microbial enzymes
}

\author{
S. K. S. Raghuvansi ${ }^{1}$, R. Prasad ${ }^{1}$, M. K. Tripathi ${ }^{1 \dagger}$, A. S. Mishra ${ }^{1}$, O. H. Chaturvedi ${ }^{1}$, \\ A. K. Misra , B. L. Saraswat ${ }^{2}$ and R. C. Jakhmola ${ }^{1}$ \\ ${ }^{1}$ Division of Animal Nutrition, Central Sheep and Wool Research Institute, Avikanagar(Via- Jaipur), Rajasthan 304 501, India; ${ }^{2}$ Department of Animal Husbandry \\ and Dairying, Udai Pratap Autonomous College, Varanasi, Uttar Pradesh 221 002, India
}

(Received 20 May 2006; Accepted 4 September 2006)

\begin{abstract}
A study to compare two feeding systems, stall feeding (SF) and grazing plus supplementation (GR) was carried out, based on intake, performance and rumen fermentation characteristics of lambs. While SF animals received ad libitum complete feed blocks (CFB), GR animals were allowed grazing for $8 \mathrm{~h}$ on a pasture and supplemented with concentrate mixture at $250 \mathrm{~g}$ per head per day. Intake in grazing animals was determined using chromium III oxide as internal marker. Intake of dry matter (DM), crude protein $(C P)$ and organic matter $(O M)$ were higher $(P<0.01)$ in $S F$ than in $G R$ animals. Similarly, digestibility of $O M, C P$ and energy were higher $(\mathrm{P}<0.01)$ in SF animals. Average daily gain in SF animals $(101 \mathrm{~g})$ was significantly $(\mathrm{P}<0.01)$ higher than in GR animals (78 g) but total wool yield was similar for the two groups (856g, SF; $782 \mathrm{~g}$, GR). The $\mathrm{pH}$ of the rumen content, concentration of total volatile fatty acids and total activities of carboxymethyl cellulase, xylanase and esterase in the rumen liquor were similar. The concentrations (mg/dl) of total nitrogen (125, SF; 63, GR) and $\mathrm{NH}_{3}$-nitrogen (42, SF; 31, GR) were higher in SF animals than that of $G R$ animals. A significantly higher activity $(P<0.05)$ of microcrystalline cellulase $(24.5 \mathrm{v} .7 .7$ units) and lower activity (P < 0.05) of protease (309 v. 525 units), was observed in the rumen of SF animals than in GR animals. SF animals could therefore harness more energy through degradation of plant cell walls thus reducing breakdown of plant proteins as gluconeogenic source. The SF system of feeding where CFB was offered to sheep appeared superior to GR in terms of intake, nutrient utilisation and animal performance. Therefore the SF feeding system where CFB are offered to animals can be advocated as an alternative to grazing and supplementation feeding strategy for sheep production, especially where the pastures are highly eroded and need resting for regeneration or curing. The CFB feeding can also be adopted under adverse conditions like drought and famine, a common phenomenon in arid and semiarid conditions.
\end{abstract}

Keywords: enzymes, grazing, rumen fermentation, sheep, stalls.

\section{Introduction}

Small ruminant production system in India is dependent mainly on community pastures that are highly degraded. Such pastures produce forages that are low in quality and are unable to provide a sustained supply of nutrients to animals. Utilisation of poor quality feeds by ruminants can be improved through concentrate supplementation, which increases the digestibility of nutrients (Santra et al., 2002) through stimulating rumen fermentation (Sultan and Loerch, 1992). Supplementation of maize, and soya-bean meal on wheat straw based diets improved digestible

\footnotetext{
${ }^{\dagger} \mathrm{E}$-mail address: msom@dr.com
}

organic matter intake (Abebe et al., 2004). Similarly, supplementation of peanut oil meal $(2.5 \mathrm{~g} / \mathrm{kg}$ live weight) resulted in higher average daily gain and was economic for growing kid production (0tt et al., 2004). A supplementation of $250 \mathrm{~g}$ concentrate in addition to grazing is now being recommended to raise sheep in semi-arid regions of India (Karim et al., 2004). Such situations have increased the pressure on supplemental feed resources under tropical animal production systems (Shem et al., 2001). Therefore, for long-term sustenance, the existing degraded pastures/ waste lands need to be revived. Development of grasslegume-based pastures is one of the recognised strategies in many countries for enhancing both the quality and quantity of feed resources that could play an important 
role in improving low input animal production systems (Shem et al., 2003). This can be done through discouraging rigorous grazing and suggesting stall-feeding. Locally available roughage-based complete feed blocks were found suitable for domestic ruminants (Jakhmola, 2005). Forage to concentrate ratio in these blocks is invariably kept at 60:40, which was required for greater intake and digestibility of dry matter (DM), organic matter (OM) and crude protein (CP) (Haddad, 2005). Adequate ruminal energy supply coupled with an appropriate amount of ruminally available nitrogen promotes microbial nitrogen synthesis and efficiency (Henning et al., 1993). Thus, complete feed blocks that contain locally available feed materials can be useful in maintaining sheep productivity under stall-feeding.

In the present study two feeding systems, complete feed block under stall-feeding and grazing plus supplementation were assessed in terms of nutrient intake and utilisation, rumen fermentation pattern and performance of lambs.

\section{Material and methods}

\section{Site and environmental conditions}

The experiment was conducted at the Central Sheep and Wool Research Institute, Avikanagar (Rajasthan, India) located at $26^{\circ} 17^{\prime} \mathrm{N}$ latitude and $75^{\circ} 28^{\prime} \mathrm{E}$ longitude and $320 \mathrm{~m}$ above seal level. The climate is hot and semi-arid. The experiment was conducted for 90 days during the winter season from September to December 2002. During the experimental period, minimum and maximum ambient temperatures ranged from $5^{\circ}$ to $12^{\circ} \mathrm{C}$ and $32^{\circ}$ to $41^{\circ} \mathrm{C}$, respectively. Relative humidity varied from 51 to $95 \%$.

\section{Selection and distribution of animals}

Twenty-two Malpura lambs $(231 \pm 2.3$ days of age and $22 \pm 0.3 \mathrm{~kg}$ live weight (LW)) were selected from the institute farm. Animals were dewormed before the experiment using 'Albendazole' at $10 \mathrm{mg} / \mathrm{kg}$ LW (Wockhardt India Ltd, Bombay). Animals were randomly divided into two groups. One group (SF) was kept under stall-feeding and received complete feed blocks (CFB) as their sole feed daily each morning. The animals were fed individually and penned in a well ventilated shed, being allowed access to an open paddock (without vegetation) for $2 \mathrm{~h}$ in the morning. Another group was maintained on grazing and supplementation (GR). The GR animals were allowed to graze a rangeland that was dominated by Cenchrus ciliaris (sward height $<20 \mathrm{~cm}$ ) for a period of $8 \mathrm{~h}$. When returned to the shed at $1700 \mathrm{~h}$, animals were fed individually a $250 \mathrm{~g}$ concentrate mixture. Water was offered ad libitum twice a day at 1000 and $1600 \mathrm{~h}$. Lambs were weighed at weekly intervals to assess health status and growth performance. The wool yield was calculated by shearing an $8 \times 8 \mathrm{~cm}$ area of left flank before and after the experiment following the procedure of Pierce (1934) using sheep surface area in metres $\left.\{\text { (surface area })^{2}=0.121(\mathrm{LW}, \mathrm{kg})^{0.59}\right\}$.
Diet preparation

The complete feed blocks had forage: concentrate ratio of 60:40. Different ingredients (composition in Table 1) were thoroughly mixed using a horizontal mixer. The mixed complete feed was then compressed at 4000 p.s.i. into CFB using a horizontal complete feed-block-making machine. The concentrate mixture given to GR animals (composition in Table 1) was in the mash form.

\section{Digestibility trial}

A digestibility trial was conducted after 45 days of initial feeding on six animals from each group that had comparable LW. Chromium III oxide $\left(\mathrm{Cr}_{2} \mathrm{O}_{3}\right)$, an indigestible marker, was used as an indicator to estimate intake (Harris, 1967). The animals on trial were dosed for 10 consecutive days with $1 \mathrm{~g} \mathrm{Cr}_{2} \mathrm{O}_{3}$ in a paper capsule twice daily at $0800 \mathrm{~h}$ and $1700 \mathrm{~h}$. The initial 5 days were allotted as adjustment period for uniform $\mathrm{Cr}_{2} \mathrm{O}_{3}$ excretion in the faeces and the later 5 days were used for faecal sample collection. The faecal samples were drawn manually from the rectum in the morning and evening hours. Samples of faeces collected over a 5-day period were pooled and representative samples were drawn. One set of samples was preserved at $-20^{\circ} \mathrm{C}$ pending nitrogen analysis by the Kjeldahl method (Association of Official Analytical Chemists (AOAC), 2000), while another set of samples was dried in an oven at 60 to $70^{\circ} \mathrm{C}$ to constant weight. The dried samples were subsequently ground

Table 1 Composition of complete feed block (CFB) supplement and grazing pasture

CFB Supplement Pasture

\begin{tabular}{lccc}
\hline Physical composition (g/kg) & & \\
Bajra kadbi (Pennisetum typhoides) & 300 & \\
Khejri leaves (Prosopis cineraria) & 100 & & \\
Pala leaves (Zizyphus nummularia) & 100 & & \\
Ardu leaves (Ailanthus excelsa) & 100 & & \\
Barley & 91.4 & 156.8 & \\
Deoiled rice bran & 91.4 & 156.8 & \\
Wheat bran & 91.4 & 156.8 & \\
Groundnut cake & 17.2 & 127.4 & \\
Mustard cake & 17.2 & 127.4 & \\
Cottonseed cake & 17.2 & 127.4 & \\
Soya-bean meal & 17.2 & 127.4 & \\
Mineral mixture & \\
Sodium chloride & 3.5 & 10.0 & \\
Molasses & 3.5 & 10.0 & \\
Chemical composition (g/kg) & 50.0 & - & \\
Organic matter & & & \\
Crude protein & 821 & 900 & 840 \\
Neutral-detergent fibre & 130 & 170 & 77 \\
Acid-detergent fibre & 536 & 473 & 572 \\
Hemicellulose & 405 & 158 & 456 \\
Cellulose & 131 & 315 & 116 \\
Lignin & 225 & 127 & 212 \\
Gross energy (MJ/kg) & 73 & 31 & 124 \\
\hline \hline
\end{tabular}

${ }^{\dagger}$ Composition (per kg): calcium $320 \mathrm{~g}$, phosphorus $62 \mathrm{~g}$, manganese $2.7 \mathrm{~g}$, zinc $2.6 \mathrm{~g}$, iron $1 \mathrm{~g}$, fluorine $900 \mathrm{mg}$, iodine $100 \mathrm{mg}$, copper $100 \mathrm{mg}$. 
to pass a 1-mm screen and stored for laboratory analysis. Dried faecal samples were analysed for $\mathrm{Cr}_{2} \mathrm{O}_{3}$ content and faecal output was determined (Harris, 1967). The faecal out put was used to determine pasture intake and nutrient digestibility by lignin ratio (Wallace and Van Dyne, 1970). In brief, the proportion of concentrate in total faecal output was estimated by the predetermined in-vitro DM digestibility of concentrate. Subtracting the faecal out put of concentrate from total faecal output, provided the faecal output from pasture intake. Pasture DM intake was then calculated $\{$ (lignin in faeces $\times$ pasture faecal output) / lignin of diet\}.

\section{Chemical analysis}

Feeds and pasture samples were analysed for DM by drying at $100^{\circ} \mathrm{C}$ for $24 \mathrm{~h}$. The samples of feed, pasture and faeces that were dried at 60 to $70^{\circ} \mathrm{C}$ and ground to pass a 1-mm sieve were used for chemical analysis. The OM was determined by ashing at $550^{\circ} \mathrm{C}$ for $4 \mathrm{~h}$ and nitrogen was determined by Kjeldahl technique (AOAC, 2000). Neutraldetergent fibre (NDF) and acid-detergent fibre (ADF) were determined by a procedure of Van Soest et al. (1991), sodium sulphite or alpha-amylase was not used for NDF determinations. Acid-detergent lignin (ADL) was determined according to the method described by Robertson and Van Soest (1981). NDF and ADF were expressed with residual ash. Gross energy was estimated using a bomb calorimeter (Gallenkamp, Middlesborough, UK).

\section{Collection and analysis of rumen liquor}

During the middle part of the experiment, rumen liquor samples from each animal were drawn at $6 \mathrm{~h}$ post feeding on 3 consecutive days. About $100 \mathrm{ml}$ of representative rumen liquor was collected from the rumen with a stomach tube using light suction. Rumen liquor $\mathrm{pH}$ was recorded immediately after collection using a digital pH meter (EC 5652, Electronic Corp. India Ltd). The rumen liquor was then strained through four layers of muslin cloth. The strained rumen liquor (SRL) samples were preserved after adding a few drop of saturated mercury II chloride solution and kept in labelled polypropylene bottles at $-20^{\circ} \mathrm{C}$ till further analysis. SRL samples were analysed for total nitrogen (total- $\mathrm{N}$; micro-Kjeldahl), ammonia nitrogen $\left(\mathrm{NH}_{3}-\mathrm{N}\right.$; Conway, 1962) and total volatile fatty acids (TVFA; Barnett and Reid, 1957). The activities of carboxymethylcellulase (CMCase), microcrystallinecellulase (MCCase), estaerase, xylanase and protease in the SRL (extra cellular, EC and cellular, C) were estimated according to Agarwal (2000) with slight modifications (Raghuvansi, 2003). Ten millilitres of fresh rumen liquor was centrifuged at 14000 r.p.m. for $20 \mathrm{~min}$ and the supernatant was used as source of enzyme for extracellular fraction. The pellet containing microbial biomass (Bacteria, protozoa and fungi) was suspended in $5 \mathrm{ml} 0.1 \mathrm{~mol} / /$ phosphate buffer $(\mathrm{pH} \mathrm{6.8)}$ and in to it, $2 \mathrm{ml}$ $\mathrm{CCl}_{4}$ and $2 \mathrm{ml}$ lysozyme $(4 \mathrm{~g} / \mathrm{l})$ was added. The suspension was then incubated for $3 \mathrm{~h}$ at $39^{\circ} \mathrm{C}$ and then centrifuged at 14000 r.p.m. for $20 \mathrm{~min}$. The supernatant was collected and used as an enzyme source for the cellular portion. The activities of each enzyme were determined separately for individual animals.

For the estimation of CMCase and xylanase, the reaction mixture contained $1 \mathrm{ml}$ phosphate buffer $(0.1 \mathrm{~mol} / /, \mathrm{pH} 6.8)$, $0.5 \mathrm{ml} \mathrm{SRL}$ and $0.5 \mathrm{ml}$ substrate (carboxymethyl cellulose; $10 \mathrm{mg} / \mathrm{ml}$ for CMCase or xylan; $2.5 \mathrm{mg} / \mathrm{ml}$ for xylanase), and was incubated at $39^{\circ} \mathrm{C}$ for 60 and $15 \mathrm{~min}$, respectively. For determining MCCase, reaction mixture that contained $1 \mathrm{ml}$ phosphate buffer $(0.1 \mathrm{~mol} / \mathrm{l} \mathrm{pH} 6.8), 1.0 \mathrm{ml} \mathrm{SRL}$ and $1.0 \mathrm{ml}$ avicel $(10 \mathrm{mg} / \mathrm{ml})$ was incubated at $39^{\circ} \mathrm{C}$ for $60 \mathrm{~min}$. The reaction was stopped by the addition of dinitro-salicylic acid reagent. The glucose thus produced was estimated according to Miller (1959). The activities of CMCase and MCCase were then calculated considering that one unit of enzyme was able to produce $1 \mu \mathrm{mol}$ glucose per hour from degradation of respective substrates. In case of xylanase activity, one unit equalled $1 \mathrm{~mol}$ of xylose that was produced per min from xylan. For estimation of the protease activity ( $\mu \mathrm{g}$ hydrolysed protein per $h$ ), the reaction mixture that contained $1 \mathrm{ml}$ buffer, $0.25 \mathrm{ml} \mathrm{SRL}$ and $0.25 \mathrm{ml}$ casein $(2.5 \mathrm{mg} / \mathrm{ml})$ was incubated for $2 \mathrm{~h}$ at $39^{\circ} \mathrm{C}$. After stopping reaction by adding trichloroacetic acid $(200 \mathrm{ml} / \mathrm{l})$, the protein was estimated (Lowry et al., 1951). The activity of esterase was determined by the method of Huggins and Lapides (1947). The assay mixture contained $0.1 \mathrm{ml} \mathrm{SRL}, 0.9 \mathrm{ml}$ substrate $(2 \mathrm{mmol} / / \mathrm{p}$-nitrophenyl acetate in phosphate buffer of $\mathrm{pH} 6.0$ ) and $2.0 \mathrm{ml}$ phosphate buffer and incubated for $10 \mathrm{~min}$ at $39^{\circ} \mathrm{C}$ and absorbance was then recorded at $410 \mathrm{~nm}$. The activity (U per $\mathrm{ml}$ ) was expressed as nmol of $p$ nitrophenol released per min under the assay condition.

Data obtained were statistically analysed using the Statistical Packages for the Social Sciences (1997) for one-way analysis of variance to assess treatment effect.

\section{Results and discussion}

\section{Chemical composition of diet}

The CP content in the supplement and in the CFB was optimum to meet the requirements of sheep (Indian Council of Agricultural Research, 1998). There was no rain during this period so, pasture was dominated by dry stubble and had $77 \mathrm{~g} \mathrm{CP}$ per $\mathrm{kg}$ DM. The values of CP and ADF content in the pasture resembled those reported by Shinde et al. (1998). The chemical composition of pasture is influenced by season (Ramirez et al., 1995; Shinde et al., 1996). The type of soil and its fertility, stocking density on the pastureland, type of grazing pasture and climate also contribute to the variability in chemical composition and nutritive value of pasture (Bryant et al., 1979; Tripathi et al., 2001). The concentrate supplement was formulated to provide adequate protein nutrition thus had higher $\mathrm{CP}$ and lower fibre fractions.

\section{Nutrient intake and digestibility}

The intake of DM by SF animals was almost 1.5 of the GR animals and was significantly $(P<0.01)$ higher in the former. This reflected in an obvious effect on $\mathrm{OM}$ and $\mathrm{CP}$ 
intake, which were also higher in the SF group. Digestibility of $\mathrm{OM}, \mathrm{CP}$ and energy was also higher $(P<0.01)$ in $\mathrm{SF}$ animals whereas, DM digestibility was not different $(P<0.05)$ between two groups (Table 2). Differences in DM intake between SF and GR groups might be due to the physical nature of the feed as well as post ingestion phenomenon. The SF sheep that were offered CFB were unable to make selection and it might have encouraged animals to eat more. Also, the even intake of concentrate and forage portions by SF animals would have improved microbial fermentation in their rumen that in turn would have increased intake. The GR animals on the other hand grazed pasture, and were supplemented with restricted quantity of concentrate mixture. It is well established that efficient microbial growth in the rumen require a balanced supply of nitrogen (amino acids and ammonia) and energy and diets containing less than $8 \% \mathrm{CP}$ limits microbial growth in the rumen (Beever, 1993). The GR animals provided concentrate supplement once in the evening, so even supply of energy could not be maintained; this could have lowered intake and nutrient utilisation. Present findings corroborate the findings of Raghuvansi et al. (2006) and Samanta et al. (2003) when complete feed blocks were fed to sheep/goats. Higher nutrient intake and digestion of the CFB diet resulted in a higher plane of nutrition of CFB fed animals.

\section{Rumen fermentation and microbial enzymes}

Total- $\mathrm{N}$ and $\mathrm{NH}_{3}-\mathrm{N}$ concentrations in the rumen were higher $(P<0.01)$ in SF animals than those of GR animals, but TVFA concentrations and $\mathrm{pH}$ were no different between the two groups (Table 3). The rumen fermentation parameters in the present study were within a normal range and comparable with those reported on complete feed mash or block (Santra et al., 2002; Samanta et al., 2003; Mishra et al., 2005). The higher concentration of total- $\mathrm{N}$ and $\mathrm{NH}_{3}-\mathrm{N}$ could be because of higher $\mathrm{CP}$ intake and digestibility (Chaturvedi and Walli, 2002). The total-N

Table 2 Nutrient intake and digestibility by SF and GR lambs $(n=12)^{\dagger}$

\begin{tabular}{|c|c|c|c|c|}
\hline & \multicolumn{2}{|c|}{ Feeding system ${ }^{\ddagger}$} & \multirow[b]{2}{*}{ s.e. } & \multirow[b]{2}{*}{ Significance } \\
\hline & SF & $\mathrm{GR}$ & & \\
\hline Live weight $(\mathrm{kg})$ & 28.9 & 28.0 & 0.30 & \\
\hline Live weight $\left(\mathrm{M}^{0.75}, \mathrm{~kg}\right)$ & 12.5 & 12.2 & 0.10 & \\
\hline \multicolumn{5}{|l|}{ Nutrient intake } \\
\hline Dry matter (g/day) & 1548 & 1080 & 86.3 & ** \\
\hline Organic matter (g/day) & 1326 & 751 & 70.8 & ** \\
\hline Crude protein (g/day) & 198 & 89 & 10.3 & ** \\
\hline \multicolumn{5}{|l|}{ Digestibility (\%) } \\
\hline Dry matter & 55.1 & 50.0 & 2.23 & \\
\hline Organic matter & 64.1 & 44.9 & 2.14 & ** \\
\hline Crude protein & 65.0 & 41.3 & 2.17 & ** \\
\hline Energy & 66.3 & 54.8 & 2.03 & ** \\
\hline
\end{tabular}

\footnotetext{
${ }^{\dagger}$ Values based on digestibility trial.

${ }^{\ddagger}$ Feeding system: SF, complete feed block fed; GR, grazing plus supplementation.
}

Table 3 Rumen fermentation characteristics of SF and GR lambs

\begin{tabular}{|c|c|c|c|c|}
\hline & \multicolumn{2}{|c|}{$\begin{array}{l}\text { Feeding } \\
\text { system }^{\dagger}\end{array}$} & \multirow[b]{2}{*}{ s.e. } & \multirow[b]{2}{*}{ Significance } \\
\hline & SF & GR & & \\
\hline $\mathrm{pH}$ & 6.4 & 6.6 & 0.09 & \\
\hline Volatile fatty acids (mmol/l) & 12.8 & 12.9 & 1.27 & \\
\hline $\mathrm{NH}_{3}$-nitrogen $(\mathrm{mg} / \mathrm{dl})$ & 42.3 & 31.2 & 2.34 & ** \\
\hline Total nitrogen (mg/dl) & 125.0 & 62.8 & 2.34 & ** \\
\hline
\end{tabular}

${ }^{\dagger}$ Feeding system: SF, complete feed block fed; GR, grazing plus supplementation.

concentration in SRL was corroborated with the findings of Punia and Sharma (1980).

The rumen microbial enzyme activities are a qualitative reflection of rumen microbes involved in the digestion of feed. Carboxymethyl cellulase is involved in the degradation of amorphous cellulose, while xylanase is responsible for degradation of pentosans. The CMCase, xylanase and protease activities in extra cellular contents were higher in GR animals than in SF animals, while activities of MCCase, an enzyme that degrades crystalline cellulose and that of acetyl esterase were higher in the later (Table 4). Cellular microbial enzymes activities were higher in SF animals than in GR animals, except esterase and protease. It is known that amylolytic and cellulolytic bacteria rapidly colonize the soluble and easily degradable carbohydrates, and this facilitates the availability of specific substrate for the renewed growth of other fibrolytic bacteria (Costerton and Cheng, 1982). The greater activities of CMCase, MCCase and xylanase in cellular fraction than liquid fraction in SF fed animals shows that the higher numbers of anaerobic microbes were attached to the solid fractions of the feed. A higher number of solid fraction associated microbes are known to increase fibrolytic enzyme activities and mainly contribute to fibre digestion (Cheng et al., 1983/1984; Cheng and McAllister, 1997).

Total (cellular plus extra cellular) CMCase, esterase and xylanase activities were similar in two groups. However, total MCCase activity was higher $(P<0.05)$ and total protease activity was lower $(P<0.05)$ in SF than in GR. It indicated that a higher amount of fibrous residue was degraded in the rumen of SF animals so more amount of energy was available which saved proteins from under going degradation for gluconeogenic purposes. Thus it is quite likely that response in microbial growth and fibrolytic micro-organism population would have been better in SF animals because of improved overall balance of energy and nitrogen supply in rumen, which is known to improve intake, nutrient utilisation and microbial growth (Sultan and Loerch, 1992; Arroquy et al., 2004).

Wool yield and growth performance

Total wool yield was similar in both groups, whereas SF resulted in a 0.29 proportionate increase in average daily gain $(P<0.01)$ in comparison with GR (Table 5$)$. Owing to 
Table 4 Rumen microbial enzymes activity (Unit) of SF and GR lambs

\begin{tabular}{|c|c|c|c|c|}
\hline & \multicolumn{2}{|c|}{ Feeding system $^{\dagger}$} & \multirow[b]{2}{*}{ s.e. } & \multirow[b]{2}{*}{ Significance } \\
\hline & SF & GR & & \\
\hline \multicolumn{5}{|c|}{ Carboxymethyl cellulase (U/h per ml) } \\
\hline Extra cellular & 42.8 & 59.9 & 2.94 & ** \\
\hline Cellular & 48.7 & 29.4 & 3.50 & ** \\
\hline Total & 91.5 & 89.3 & 4.79 & \\
\hline \multicolumn{5}{|c|}{ Microcrytalline cellulase (U/h per ml) } \\
\hline Extra cellular & 9.8 & 2.5 & 1.94 & * \\
\hline Cellular & 14.7 & 5.2 & 4.61 & \\
\hline Total & 24.5 & 7.7 & 4.57 & * \\
\hline \multicolumn{5}{|c|}{ Esterase (U/min per ml) } \\
\hline Extra cellular & 21.8 & 6.1 & 4.10 & * \\
\hline Cellular & 40.5 & 29.8 & 7.20 & \\
\hline Total & 62.3 & 35.9 & 9.71 & \\
\hline \multicolumn{5}{|c|}{ Xylanase (U/min per ml) } \\
\hline Extra cellular & 210.6 & 325.2 & 16.13 & ** \\
\hline Cellular & 273.5 & 202.7 & 15.70 & * \\
\hline Total & 484.1 & 527.9 & 29.38 & \\
\hline \multicolumn{5}{|c|}{ Protease (U/h per ml) } \\
\hline Extra cellular & 67.0 & 189.2 & 29.73 & * \\
\hline Cellular & 242.0 & 336.2 & 58.97 & \\
\hline Total & 309.0 & 525.4 & 66.32 & * \\
\hline
\end{tabular}

${ }^{\dagger}$ Feeding system: SF, complete feed block fed; GR, grazing plus supplementation.

higher nutrient intake and favourable rumen microbial activities in the rumen, SF animals were in higher plane of nutrition that of $G R$ animals. Moreover the forage to concentrate ratio was also narrower (60:40) in SF than in GR animal diet (77: 23). Required quantities of concentrate intake in SF group would have increased the availability of readily available carbohydrates that are known to improve animal performance and growth (Lee et al., 2001) because of increased efficiency of nitrogen and protein in ruminants (Arroquy et al., 2004).

\section{Conclusions}

The SF animals had higher intake and digestibility, average daily gain and ruminal activity of MCCase and lower ruminal activity of protease than that of GR animals. Therefore the SF feeding system where CFB were offered to animals can

Table 5 Wool yields and performance of lambs on complete feed block or grazing with supplement feeding

\begin{tabular}{lcccc}
\hline \hline & \multicolumn{2}{c}{$\begin{array}{c}\text { Feeding } \\
\text { system }\end{array}$} & & \\
\cline { 2 - 3 } & SF & GR & s.e. & Significance \\
\hline Wool yield (g) & 856 & 782 & 48.7 & \\
Growth performance & & & & \\
$\quad$ Initial live weight $(\mathrm{kg})$ & 22.1 & 22.1 & 0.46 & \\
$\quad$ Final live weight $(\mathrm{kg})$ & 31.0 & 29.0 & 0.48 & $* *$ \\
$\quad$ Total gain (kg) & 8.9 & 6.9 & 0.32 & $* *$ \\
$\quad$ Average daily gain $(\mathrm{g})$ & 101 & 78 & 3.7 & $* *$ \\
\hline \hline
\end{tabular}

\footnotetext{
${ }^{\dagger}$ Feeding system: SF, complete feed block fed; GR, grazing plus supplementation.
}

be advocated as an alternative to grazing and supplementation feeding strategy for sheep production, especially where the pastures are highly eroded and need resting for regeneration/curing. Feeding of CFB can also be adopted under adverse situations such as drought or famine, which are common phenomena in arid and semi-arid regions.

\section{Acknowledgements}

The authors wish to thank the Director for providing the facilities to carry out this experiment. Funding provided by NATPIAED (ARID)/PAL 028/99 is greatly appreciated. The senior author is very grateful to PIU of NATP for providing financial help through a Senior Research Fellowship.

\section{References}

Abebe G, Merkel RC, Animut G, Sahlu T and Goetsch AL 2004. Effects of ammoniation of wheat straw and supplementation with soybean meal or broiler litter on feed intake and digestion in yearling Spanish goat wethers. Small Ruminant Research 51, 37-46.

Agarwal N 2000. Estimation of fibre degrading enzyme. In Feed microbiology (eds LC Chaudhary, N Agarwal, DN Kamra and DK Agarwal), pp. 278-291. CAS Animal Nutrition, IVRI, Izatnagar, India.

Association of Official Analytical Chemists 2000. Official methods of analysis of the AOAC International, 17th edition, vol. 1 and 2. Association of Official Analytical Chemists, Gaithersburg, MD

Arroquy Jl, Cochran RC, Villarreal $M$, Wickersham TA, Llelwellyn $D A$, Titgemeyer EC, Nagaraja TG, Johnoson DE and Gnad D 2004. Effect of level of rumen degradable protein and type of supplemental non-fibre carbohydrate on intake and digestion of low quality hay by beef cattle. Animal Feed Science and Technology 115, 83-99.

Barnett AJG and Reid RL 1957. Studies on the production of volatile fatty acids from grass by rumen liquor in an artificial rumen. IThe volatile fatty acid Production of fresh grass. Journal of Agricultural Science, Cambridge 48, 315-321.

Beever DE 1993. Rumen function. In Quantitative aspects of ruminant digestion and metabolism (eds JM Forbes and JM France), pp. 187-215. CAB International, Oxon.

Bryant FC, Kothmann MM and Merrill LB 1979. Diets of sheep, Angora goats, Spanish goats and White tailed deer under excellent range condition. Journal of Range Management 32, 412-417.

Chaturvedi $\mathrm{OH}$ and Walli TK 2002. Rumen metabolites in crossbred calves fed graded levels of rumen degraded protein and undegraded dietary protein. Indian Journal of Animal Science 72, 991-995.

Cheng K-J and McAllister TA 1997. Compartmentation in the rumen. In The rumen microbial ecosystem (eds PN Hobson and CS Stewart), pp. 492-522. Chapman and Hall, London.

Cheng K-J, Stewart CS, Dinsdate D and Cosertor JW 1983/1984. Electron microscopy of bacteria involved in the digestion of plant walls. Animal Feed Science and Technology 10, 93-120.

Conway EJ 1962. Micro-diffusion analysis and volumetric error, fifth edition. Lockwood and Sons Ltd, London.

Costerton JW and Cheng K-J 1982. Microbe-microbe interactions at surface. In Experimental microbial ecology (eds RG Burns and JH Slater), pp. 275-290. Blackwell Scientific, London.

Haddad SG 2005. Effect of dietary forage: concentrate ratio on growth performance and carcass characteristics of growing Baladi kids. Small Ruminant Research 57, 43-49.

Harris LE 1967. Nutrient research technique for domestic and wild animals, vol. 1. Agricultural Services, Logan, Utah.

Henning PH, Steyn DG and Meissner HH 1993. Effect of synchronization of energy and nitrogen supply on ruminal characteristics and microbial growth. Journal of Animal Science 71, 2516-2528. 
Huggins C and Lapides J 1947. Acetyl esters of p-nitrophenol as substrate for the colorimetric determination of esterase. Journal of Biological Chemistry $170,467-482$

Indian Council of Agricultural Research 1998. Nutrient requirement of animals. ICAR, New Delhi, India.

Jakhmola RC 2005. The final report (1999-2005): evaluation of locally available feed and fodder to improve quality and formulate complete economic rations with high roughage diets. Central Sheep and Wool Research Institute, Avikanagr, India.

Karim SA, Santra A and Singh VK 2004. Lamb feeding for mutton production. Central Sheep and Wool Research Institute, Avikanagr, India.

Lee MRF, Jones EL, Moorby JM, Humphrey MO, Thedorou MK, MacRae JC and Scollan ND 2001. Production responses for lamb grazed on Lolium perenne selected from an elevated water-soluble carbohydrate concentration. Animal Research 50, 441-449.

Lowry OH, Rosebrough NJ, Farr AL and Randall RJ 1951. Protein measurement with the Pholin-phenol reagent. Journal of Biological Chemistry 193, 262-275.

Miller JL 1959. Modified DNS method for reducing sugars. Analytical Chemistry 31, 426-429.

Mishra AS, Tripathi MK, Chaturvedi OH, Misra AK, Raghuvansi SKS, Prasad R and Jakhmola RC 2005. Comparative nutrient utilisation and rumen fermentation in sheep on complete feed mixture (Mash) or block diet. In Proceedings of the national seminar on conservation, processing and utilisation of monsoon herbage for augmenting animal production. December 17-18, CSWRI Bikaner, India, p 183.

Ott JP, Muir JP, Brown TF and Wittie RD 2004. Peanut meal supplementation for growing doe kids on woodland range. Small Ruminant Research 52, 63-74.

Pierce A 1934. Council of Scientific and Industrial Research bulletin no. 84 . Cited from Alexander G 1964. Temperature regulation in newborn lambs, metabolic rate, body temperature and RQ. Australian Journal of Agriculture Research 12, 1152-1174.

Punia BS and Sharma DD 1980. Effect of roughage and concentrate ratios on nitrogen metabolites in buffalo rumen. Indian Journal of Nutrition and Dietetics 17, 60-65.

Raghuvansi SKS 2003. Preparation and testing of high roughage based complete feed block in sheep feeding Ph.D. thesis, Udai Pratap Autonomous College, Varanasi, UP, India.

Raghuvansi SKS, Tripathi MK, Mishra AS, Chaturvedi OH, Prasad R, Saraswat BL and Jakhmola RC 2006. Feed digestion, rumen fermentation and blood constituents in Malpura rams fed a complete feed-block diet with the inclusion of tree leaves. Small Ruminant Research, (in press).
Ramirez RG, Alonso DS, Hernandez G and Ramirez B 1995. Nutrition intake of range sheep on a buffelgrass (Cenchrus ciliaris) pasture. Small Ruminant Research 17, 123-128.

Robertson JB and Van Soest PJ 1981. The detergent system of analysis and its application to human foods. Cornell University, Ithaca, New York.

Samanta AK, Singh KK, Das MM, Maity SB and Kundu SS 2003. Effect of complete feed block on nutrient utilization and rumen fermentation in Barbari goats. Small Ruminant Research 48, 95-102.

Santra A, Karim SA and Chaturvedi $\mathrm{OH}$ 2002. Effect of concentrate supplementation on nutrient intake and performance of lamb of two genotypes grazing a semi-arid rangeland. Small Ruminant Research 44, 37-45.

Shem MN, Kakeni AM, Mtengeti EJ and Otsyina R 2001. Performance of grazing dairy cattle in semi-arid area of Western Tanzania and the marginal productivity of Leucaena leucocephala leaf meal supplement. Agroforestry Systems Research 52, 73-82.

Shem MN, Mtengeti EJ, Luaga M, Ichinohe T and Fujihara T 2003. Feeding value of wild Napier grass (Pennisetum macrourum) for cattle supplemented protein/ or energy rich supplements. Animal Feed Science and Technology $108,15-25$.

Shinde AK, Karim SA and Patnayak BC 1996. Seasonal changes in circulating mineral contents of sheep and goats on different of pasture. Indian Journal of Small Ruminants 2, 23-27.

Shinde AK, Karim SA, Sankhyan SK and Bhatta R 1998. Seasonal changes in biomass growth and quality and its utilization by sheep on semi-arid Cenchrus ciliaris pasture of India. Small Ruminants Research 30, 29-35.

Statistical Packages for the Social Sciences 1997. Base 10 SPSS software products. SPSS Inc., Chicago, IL.

Sultan JI and Loerch SC 1992. Effect of protein and energy supplementation of wheat straw-based diets on side of nutrient digestion and nitrogen metabolism of lamb. Journal of Animal Science 70, 2228-2234.

Tripathi MK, Mishra AS, Misra AK and Karim SA 2001. Soil estimates (pH, N and $\mathrm{OM}$ ), biomass yield and chemical composition of vegetation of community range land in semi-arid region of Rajasthan. Indian Journal of Animal Science 71, 285-286.

Van Soest PJ, Robertson JB and Lewis BA 1991. Methods for dietary fiber, neutral detergent fiber and nonstarch polysaccharides in relation to animal nutrition. Symposium: carbohydrate methodology, metabolism and nutritional implications in dairy cattle. Journal of Dairy Science 74 , 3583-3597.

Wallace JD and Van Dyne GM 1970. Precision of indirect method for estimating digestibility of forage consumed by grazing cattle. Journal of Range Management 23, 423-430. 